Özgün Araştırma

Research Article

Received/Geliș: 13.05.2021

Accepted/Kabul: 21.05.2021

First Online: 28.09.2021

Uygar Miçooğulları

S.B.Ü. Tepecik Eğitim ve Araştırma Hastanesi Üroloji Anabilim Dalı, İzmir, Türkiye uygarmico@hotmail.com ORCID: 0000-0003-4729-6104

O. Çelik 0000-0001-6612-1831

E. Kısa 0000-0002-4728-3808

C. Yücel 0000-0003-0838-9199

O.N. Yalbuzdağ 0000-0001-6172-3411

M. Yoldaş 0000-0001-5031-0435

H. Üçok 0000-0002-9042-8152

T. Süelözgen 0000-0003-0790-3926

M.Z. Keskin 0000-0002-9206-5586

Y.ö. İlbey 0000-0002-1483-9160

S.B.Ü. Tepecik Eğitim ve Araştırma Hastanesi Üroloji Anabilim Dalı, izmir, Türkiye

M.Ç. Çakıcı 0000-0002-0176-5887 Istanbul Medeniyet Üniversitesi Tıp Fakültesi Üroloji Anabilim Dalı, Istanbul, Türkiye

Cite as: Miçooğulları U, Çelik O, Çakıcı MÇ, Kıs E, Yücel $C$, Yalbuzda , Yüce C, Yalbuzdağ ON, et al. Can preor tive neutrophillymphocyte ratio and plateletymphocyte ratio predict systemic inflamm tory response syndrome that develops after percutaneous nephrolithotomy?. Tepecik Eğit. ve Araşt. Hast. Dergisi. 2021;31(3):362-7.

\section{Can Preoperative Neutrophil-Lymphocyte Ratio and Platelet-Lymphocyte Ratio Predict Systemic Inflammatory Response Syndrome That Develops After Percutaneous Nephrolithotomy?}

\author{
Preoperatif Nötrofil-Lenfosit Oranı ve Trombosit-Lenfosit \\ Oranı, Perkütan Nefrolitotomi Sonrası Gelişen Sistemik \\ Inflamatuar Yanıt Sendromunu Öngörebilir mi?
}

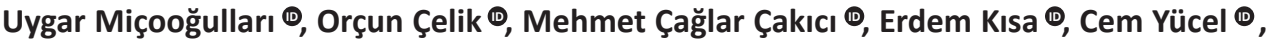 \\ Okan Nabi Yalbuzdağ $\odot$, Mehmet Yoldaş $\odot$, Hakan Üçok $\odot$, Tufan Süelözgen $\odot$, \\ Mehmet Zeynel Keskin ๑, Yusuf Özlem İlbey $\odot$
}

\begin{abstract}
Objective: First objective of this study was to find out factors influencing development of postoperative systemic inflammatory response syndrome (SIRS) after percutaneous nephrolithotomy (PNL). Secondary objective was to point out the role of preoperative neutrophil-lymphocyte ratio (NLR) and platelet-lymphocyte ratio (PLR) in SIRS estimation.

Method: The data of 756 patients that underwent PNL for kidney stones between 2012 and 2019 were evaluated retrospectively. Patients were divided into 2 groups as non-SIRS and SIRS group. The effects of NLR, PLR and other operative and demographic variables on development of SIRS were investigated. Multivariate logistic regression analysis that was performed on variables that were significant in the univariate analyses was used to establish independent risk factor for post-PNL SIRS.

Results: Univariate analysis revealed a significant association between presence of SIRS and preoperative $P L R(p<0.001)$, preoperative NLR $(p<0.001)$, blood transfusion $(p<0.001)$, stone volume $(p=0.03)$, staghorn stone $(p<0.001)$, and preoperative creatinine levels $(<0.001)$. Multivariate logistic regression analyses of these risk factors showed that NLR $(p<0.001), P L R(p<0.001)$, and blood transfusions $(p<0.001)$ were independently associated with SIRS. When the cut-off value of PLR was 120.5, the development of SIRS was predicted with $80.1 \%$ specificity and $81 \%$ sensitivity. When the cut-off value of NLR was 2.75, the development of SIRS was predicted with $64 \%$ specificity and $63.7 \%$ sensitivity.

Conclusion: Preoperative PLR and NLR are effective and inexpensive biomarkers that can be used to predict SIRS and sepsis after PNL. We recommend that patients with PLR $>120.5, N L R>2.75$, and blood transfusions should be monitored closely due to the possible development of serious complications.
\end{abstract}

Keywords: Neutrophil lymphocyte ratio, platelet-lymphocyte ratio, systemic inflammatory response syndrome, percutaneous nephrolithotomy, sepsis

Öz

Amaç: Bu çalıșmanın ilk amacl; perkütan nefrolitotomi (PNL) sonrası postoperatif sistemik inflamatuar yanıt sendromunun (SIRS) gelişimini etkileyen faktörleri ortaya koymaktır. ikincil amaç; SIRS gelişiminde preoperatif trombosit-lenfosit oranının (PLR) ve nötrofil-lenfosit oranının (NLR) rolünü belirlemektir.

Yöntem: Calısmaya 2012-2019 yılları arasında böbrek tassları için PNL uygulanan ve verileri retrospektif toplanan 756 hasta dahil edildi. Hastalar SIRS olmayan (nonSIRS grup) ve SIRS olan (SIRS grup) grup olarak 2 ye ayrildı. PLR, NLR, diğer demografik ve operatif verilerin SIRS gelişimini ürerine etkileri araştırıldı. Tek değişkenli analizde anlamlı çıkan değişkenler, PNL'den sonra SIRS gelișimi için bağımsız risk faktörlerini belirlemek amacıyla çoklu lojistik regresyon modeli kullanılarak değerlendirildi.

Bulgular: Tek değişkenli analiz SIRS grubu ile preoperatif $P L R(P<, 001)$, preoperatif $N L R(P<0,001)$, kan transfüyonu $(<0,001)$, tas volümü $(p=0,03)$, staghorn taș $(p<0,001)$ ve preoperatif kreatinin değeri $(<0,001)$ parametreleri arasında istatistiksel anlamlı bir iliski olduğunu ortaya koydu. Cok değiskenli lojistik regresyon analizleri NLR $(p<0,001)$, PLR $(p<0,001)$ ve kan transfüzyonu'nun $(p<0,001)$, SIRS ile bağımsız olarak iliskili olduğunu gösterdi. PLR'nin cut-off değeri 120,5 olarak alındığında, SIRS gelișimininin \%81 duyarlılı ve \%80,1 özgüllük ile tahmin edildiği, NLR'nin cut-off değeri 2,75 olarak alındığında SIRS gelişiminin \%63,7 duyarlıık ve \%64 özgüllük ile tahmin edildiği izlendi.

Sonuç: Preoperatif PLR ve NLR, PNL'den sonra SIRS ve sepsisi tahmin etmek için kullanılabilecek etkili ve ucuz biyobelirteçlerdir. Ciddi komplikasyonların olası gelișim ihtimaline karșın nedeniyle PLR> 120,5, NLR >2,75 olan kan transfüzyonu yapılan hastaları yakından izlenmesini önermekteyiz.

Anahtar kelimeler: Nötrofil lenfosit oranı, trombosit lenfosit oranı, sistemik inflamatuar yanıt sendromu, perkütan nefrolitotomi, sepsis

(c) Telif hakkı T.C. Sağlık Bakanlığı İmir Tepecik Eğit. ve Araşt. Hastanesi. Logos Tıp Yayıncılık tarafindan yayınlanmaktadır. Bu dergide yayınlanan bütün makaleler Creative Commons Attf-GayriTicari 4.0 Uluslararası Lisansı ile lisanslanmıștır.

(c) Copyright Association of Publication of the T.C. Ministry of Health İmir Tepecik Education and Research Hospital. This journal published by Logos Medical Publishing.

Licenced by Creative Commons Attribution-NonCommercial 4.0 International (CC BY-NC 4.0) 


\section{INTRODUCTION}

Percutaneous nephrolithotomy (PNL) is a minimally invasive highly successful technique recommended as the first-line treatment for kidney stones of $\geq 2 \mathrm{~cm}$ (1). Despite its high success rates, PNL is associated with some complications. Sepsis is one of the most important complications and occurs in $0.3 \%$ to $3.1 \%$ of patients ${ }^{(2)}$. Reported mortality rates among those range from $25 \%$ to $50 \%{ }^{(3,4)}$.

Ischemic inflammatory response syndrome (SIRS), characterized by both infectious and non-infectious inflammation, is closely associated with the development of sepsis. Some studies have investigated the factors affecting the development of SIRS and febrile status after PNL ${ }^{(5-8)}$. Plateletlymphocyte ratio (PLR) and neutrophil-lymphocyte ratio (NLR) are biomarkers that increase during inflammation ${ }^{(5,6,9)}$. Both PLR and NLR have been reported to be promising biomarkers in predicting prognosis and diagnosis in varied inflammatory response cancers and diseases ${ }^{(9)}$. Moreover, it has been reported that patients with kidney stones have higher NLR and PLR rates compared to those without kidney stones ${ }^{(9)}$.

The literature examining the effect of NLR and PLR on the development of SIRS after PNL is quite limited ${ }^{(5,9)}$. In this study, we aimed to investigate whether preoperative PLR and NLR could be used as effective inflammatory markers in predicting the occurrence of SIRS after PNL.

\section{MATERIAL and METHODS}

After approval of the local ethics committee, medical records of 1011 patients that underwent PNL operation in our clinic between 2012 and 2019 were retrospectively reviewed. Nurse observations were also evaluated. Patients under 18 years of age, patients that had any SIRS criteria during preoperative evaluation, patients with previous nephrostomy tube or urinary stent placement, patients with oncological disease, those who underwent simultaneous ipsilateral or contralateral ureteroscopic intervention or bilateral PNL, patients that didn't have preoperative abdominal computed tomography (CT) images, and those with positive urine culture and any missing data were excluded from the study. A total of 756 patients were included in the study. The patients were divided into 2 groups depending on whether they developed SIRS postoperatively: non-SIRS group $(n=577)$ and SIRS group $(n=179)$. SIRS was defined as the presence of any two of these criteria: body temperature $<36^{\circ} \mathrm{C}$ or $>38^{\circ} \mathrm{C}$, heart rate $>90 \mathrm{bpm}$, respiratory rate $>20$ breaths/minute, $\mathrm{PaCO}_{2}$ of $<32$ $\mathrm{mmHg}$ and white blood cell (leukocyte) count $>12.000 / \mathrm{mm}^{3}$ or $<4.000 / \mathrm{mm}^{3}$, and more than $10 \%$ immature forms ${ }^{(10)}$.

Demographic and clinical data such as detailed medical histories and physical examinations, urinalysis, urine culture, complete blood count, serum biochemical values, American Society of Anesthesiology (ASA) score, stone size and location, preoperative NLR and PLR rates, decrease in hemoglobin, blood transfusion status, stone-free rate, and complication rates were analyzed in both groups. Complications were evaluated according to the Clavien classification. Patients were defined as stone-free if they didn't have any renal stones in the postoperative fluoroscopic imaging and $1^{\text {st }}$ month tomography.

\section{Surgical Procedure}

After administering general anesthesia, all patients were placed in the lithotomy position and 6-Fr catheter was placed in the ureter under cystoscopic guidance. Then, patients were switched to prone position. The ureter catheter was used to inject an opaque material and calyx suitable for access was identified with fluoroscope. Then, the guiding catheter was inserted following the insertion of 18-gauge metal needle. Based on the single-step method, 6-Fr amplatz dilator was used to dilate the entry route, which was further dilated with 28-30 Fr amplatz dilator. The stone was reached with $24 \mathrm{Fr}$ nephroscope and was broken with an ultrasonic lithotripter. At the end of the surgery, a $14 \mathrm{Fr}$ malecot 
catheter was placed in some patients if they had residue or bleeding. This catheter was removed at the postoperative $1^{\text {st }}$ to $3^{\text {rd }}$ day.

\section{Statistical analysis:}

Comparison of categorical variables was performed by Pearson chi-square test and the Z-test was utilized for the others after Bonferroni method correction. Normality of the data was analyzed using the Kolmogorov-Smirnov test. For descriptive statistics, continuous variables with normal distribution were presented as meantstandard deviation and the variables fitting the normal distribution were evaluated by the Student's t-test. Likelihood of a type I error was considered $\alpha=0.05$ for all tests. In addition, we performed univariate and multivariate logistic regression analysis to calculate odds ratio (OR) and 95\% confidence interval $(\mathrm{Cl})$ to identify risk factors predicting SIRS following PNL. Receiver operating characteristic (ROC) was used to evaluate the cut-off points of PLR and NLR values. Statistical analyses were performed using the IBM SPSS V22 packaged software program.

\section{RESULTS}

A total of 756 patients were included in the study. The non-SIRS group consisted of 577 patients and the SIRS group had 179 patients. Postoperative SIRS rate was $23.6 \%$, while the total sepsis rate was $1.5 \%$. The mean age of the patients was $48.6 \pm 13.6$ years. The mean stone size was $646.8 \pm 686 \mathrm{~mm}^{2}$. The mean PLR was $115.6 \pm 21.6$, and the mean NLR

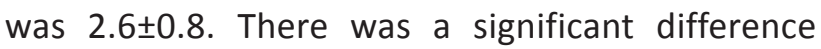
between the groups in terms of stone location (staghorn stone), stone volume, preoperative creatinine level, creatinine change, NLR, PLR, and blood transfusion parameters $(p<0.05)$. The rate of total complications and sepsis was higher in the SIRS group $(p<0.05)$. The demographic characteristics and comparative $p$ values of the groups are summarized in Table 1.

Binary logistic regression analysis was used to determine independent risk factors for SIRS.
Univariate analysis revealed a statistical association between SIRS and preoperative PLR $(p<0.001)$, preoperative NLR $(p<0.001)$, blood transfusions $(<0.001)$, stone volume $(p=0.03)$, staghorn stones $(p<0.001)$, and preoperative creatinine values $(<0.001)$. Multivariate logistic regression analyses of the risk factors that were shown to be significant in the univariate regression analyses revealed that NLR (95\% Confidence Interval $(\mathrm{Cl}): 1.67-2.85$, odds ratio $(O R)=2.18, p<0.001)$, PLR (95\% Cl: 1.07-1.10, OR=1.08, $\mathrm{p}<0.001$ ), and blood transfusions (95\% Cl: $1.35-5.02$, $\mathrm{OR}=2.61, \mathrm{p}<0.001)$ were independently associated with SIRS (Table 2).

Table 1. The groups' demographic characteristics and comparative $p$ values.

\begin{tabular}{|c|c|c|c|}
\hline & SIRS group $(n=577)$ & Non SIRS group ( $n=179$ ) & P value \\
\hline Age & $48.4 \pm 13.4$ & $49.5 \pm 14.2$ & 0.358 \\
\hline Gender. $n$ (\%) & & & 0.607 \\
\hline Female & 199 (34.5) & $58(32.4)$ & \\
\hline Male & $378(65.5)$ & $121(67.6)$ & \\
\hline ASA. $n(\%)$ & & & 0.412 \\
\hline 1 & $382(66.2)$ & $109(60.9)$ & \\
\hline 2 & $175(30.3)$ & 62 (34.6) & \\
\hline 3 & $20(3.5)$ & $8(4.5)$ & \\
\hline Side (right/left) & $251 / 326$ & $78 / 101$ & 0.986 \\
\hline Stone localization. $\mathbf{n}(\%)$ & & & $<0.001^{2}$ \\
\hline Calyx & $225(39)$ & $32(17.9)$ & \\
\hline Renal pelvis & 236 (40.9) & 78 (43.6) & \\
\hline Staghorn & $116(20.1)$ & $69(38.5)$ & \\
\hline Stone size. $\mathrm{mm}$ & $27.3 \pm 12.1$ & $25.9 \pm 10.8$ & 0.165 \\
\hline Stone volume. $\mathrm{mm}^{2}$ & $615.8 \pm 682.9$ & $747.0 \pm 691.8$ & 0.027 \\
\hline HU & $1022 \pm 329$ & $1022 \pm 333$ & 0.999 \\
\hline Stone-skin distance. $\mathrm{mm}$ & $93.5 \pm 19.8$ & $95.9 \pm 17.2$ & 0.160 \\
\hline ESWL history & 191 (33.1) & 65 (36.3) & 0.428 \\
\hline Surgical history. $\mathbf{n}(\%)$ & & & 0.108 \\
\hline Absent & $420(72.8)$ & $142(79.3)$ & \\
\hline URS & $75(13)$ & 22 (12.3) & \\
\hline PNL & $82(14.2)$ & $15(8.4)$ & \\
\hline Intercostal access. $\mathbf{n}(\%)$ & $27(4.7)$ & $9(5.1)$ & 0.837 \\
\hline Preoperative creatinine & $1.01 \pm 0.22$ & $1.09 \pm 0.34$ & 0.001 \\
\hline Creatinine change & $0.017 \pm 0.159$ & $0.074 \pm 0.227$ & $<0.001$ \\
\hline Number of renal accesses & $1.2 \pm 0.4$ & $1.2 \pm 0.4$ & 0.411 \\
\hline Operation time. $\min$ & $111.0 \pm 38.6$ & $116.2 \pm 44.1$ & 0.124 \\
\hline $\begin{array}{l}\begin{array}{l}\text { Nephrostomy placement. } n \\
(\%)\end{array} \\
\end{array}$ & $372(64.5)$ & $118(65.9)$ & 0.723 \\
\hline Catheter duration. days & $1.1 \pm 0.4$ & $1.1 \pm 0.5$ & 0.978 \\
\hline NLR & $2.5 \pm 0.8$ & $3.1 \pm 1.0$ & $<0.001$ \\
\hline PLR & $108.8 \pm 16.0$ & $137.7 \pm 22.7$ & $<0.001$ \\
\hline Hemoglobin drop $(\mathrm{g} / \mathrm{dL})$ & $1.7 \pm 1.3$ & $1.9 \pm 1.4$ & 0.117 \\
\hline Blood transfusions. $n$ (\%) & $46(8)$ & $34(19)$ & $<0.001$ \\
\hline Stone free rate. $\mathrm{n}(\%)$ & $393(68.1)$ & $122(68.2)$ & 0.991 \\
\hline Sepsis. n (\%) & $6(1)$ & $8(4.5)$ & 0.003 \\
\hline Clavien-Dindo score. $\mathbf{n}(\%)$ & & & 0.006 \\
\hline C1 & 67 (11.6) & $18(10.1)$ & \\
\hline C2 & $82(14.2)$ & $41(22.9)$ & \\
\hline C3a & $5(0.9)$ & $3(1.7)$ & \\
\hline c3b & $5(0.9)$ & $2(1.1)$ & \\
\hline C4a & $4(0.7)$ & $4(2.2)$ & \\
\hline C4b & $1(0.2)$ & $3(1.7)$ & \\
\hline C5 & $1(0.2)$ & $1(0.6)$ & \\
\hline Complications. $\mathrm{n}(\%)$ & & & 0.006 \\
\hline Minor (C1-2) & 561 (97.2) & $166(92.7)$ & \\
\hline Major (C3-5) & $16(2.8)$ & $13(7.3)$ & \\
\hline Length of hospital stay (day) & $2.3 \pm 1.8$ & $2.3 \pm 1.5$ & 0.788 \\
\hline
\end{tabular}

z: Z-test

ASA, American Society of Anesthesiologists; HU, Hounsefield Unit; PNL, percutaneous nephrolithotomy; URS, ureteroscopy; ESWL, Extra Corporeal Shock Wave Lithotripsy; NLR, neutrophil-lymphocyte ratio; PLR, platelet-lymphocyte ratio (PLR). 
Table 2. Multivariate logistic regression analysis of risk factors predicting the development of SIRS after PNL.

\begin{tabular}{|c|c|c|c|c|c|c|c|c|}
\hline \multicolumn{9}{|c|}{ Binary Logistic Regression ( $\mathrm{n}=756$ ) } \\
\hline \multirow[b]{3}{*}{ Age } & \multicolumn{4}{|c|}{ Univariate Model } & \multicolumn{4}{|c|}{\begin{tabular}{|l} 
Multivariate Model \\
\end{tabular}} \\
\hline & OR & $95 \% \mathrm{Cl}$ & & \begin{tabular}{|l|}
$\mathbf{P}$ \\
\end{tabular} & \multirow[t]{2}{*}{ OR } & \multicolumn{2}{|l|}{$95 \% \mathrm{Cl}$} & \multirow{2}{*}{\begin{tabular}{|l|}
$P$ \\
value
\end{tabular}} \\
\hline & 1.006 & 0.993 & 1.018 & 0.357 & & & & \\
\hline Gender & 0.911 & 0.637 & 1.301 & 0.607 & & & & \\
\hline ASA & 1.218 & 0.909 & 1.631 & 0.187 & & & & \\
\hline Staghorn stone & 2.493 & 1.733 & 3.585 & $<0.001$ & & & & \\
\hline Stone size & 0.989 & 0.975 & 1.004 & 0.165 & & & & \\
\hline Stone volume & $\begin{array}{l}1.0002 \\
47\end{array}$ & 1.000024 & $\begin{array}{l}1.00047 \\
0\end{array}$ & 0.030 & & & & \\
\hline ESWL history & 1.152 & 0.812 & 1.636 & 0.428 & & & & \\
\hline Surgical history & 0.761 & 0.585 & 0.989 & \begin{tabular}{|l|l|}
0.041 \\
\end{tabular} & & & & \\
\hline $\begin{array}{l}\text { Preoperatif } \\
\text { kreatinin değeri }\end{array}$ & 2.767 & 1.501 & 5.099 & 0.001 & & & & \\
\hline $\begin{array}{l}\text { Preoperative } \\
\text { creatinine }\end{array}$ & 1.003 & 0.999 & 1.007 & 0.124 & & & & \\
\hline $\begin{array}{l}\text { Number of } \\
\text { renal accesses }\end{array}$ & 0.844 & 0.563 & 1.264 & 0.411 & & & & \\
\hline NLR & 2.460 & 1.974 & 3.067 & $<0.001$ & 2.186 & 1.674 & 2.855 & $<0.001$ \\
\hline PLR & 1.090 & 1.075 & 1.106 & $<0.001$ & 1.088 & 1.072 & 1.104 & $<0.001$ \\
\hline $\begin{array}{l}\text { Hemoglobin } \\
\text { drop }\end{array}$ & 1.103 & 0.976 & 1.248 & 0.117 & & & & \\
\hline $\begin{array}{l}\text { Blood } \\
\text { transfusion }\end{array}$ & 2.707 & 1.675 & 4.373 & $<0.001$ & 2.612 & 1.358 & 5.023 & $<0.001$ \\
\hline Stone free rate & 0.998 & 0.696 & 1.430 & 0.991 & & & & \\
\hline
\end{tabular}

ASA, American Society of Anesthesiologists; HU, Hounsefield Unit; PNL, percutaneous nephrolithotomy; URS, ureteroscopy; ESWL, Extra Corporeal Shock Wave Lithotripsy; NLR, neutrophil-lymphocyte ratio; PLR, platelet-lymphocyte ratio (PLR).

ROC curve analysis showed that PLR and NLR had predictive value for SIRS following PNL. The area under ROC curve (AUC) was 0.854 [95\% confidence interval $(95 \% \mathrm{Cl})=0.820-0.887, \mathrm{p}<0.001]$. ROC curve analysis provided a PLR value of 120.5 as a cut-off point for postoperative SIRS development (sensitivity $=81 \%$, specificity $=80.1 \%$ ).

The AUC was 0.684 [95\% confidence interval (95\% $\mathrm{Cl})=0.636-0.731, \mathrm{p}<0.001$, Figure 1] and ROC curve analysis provided a NLR value of 2.75 -value as a cutoff point for postoperative SIRS development (sensitivity=63.7\%, specificity=64\%).

Patients that are at risk for developing SIRS after PNL could be identified by using cut-off points of 120.5 and 2.75 for PLR and NLR, respectively. Considering the sensitivity, specificity and predictive values, it was determined that PLR was a more valuable predictor for SIRS.

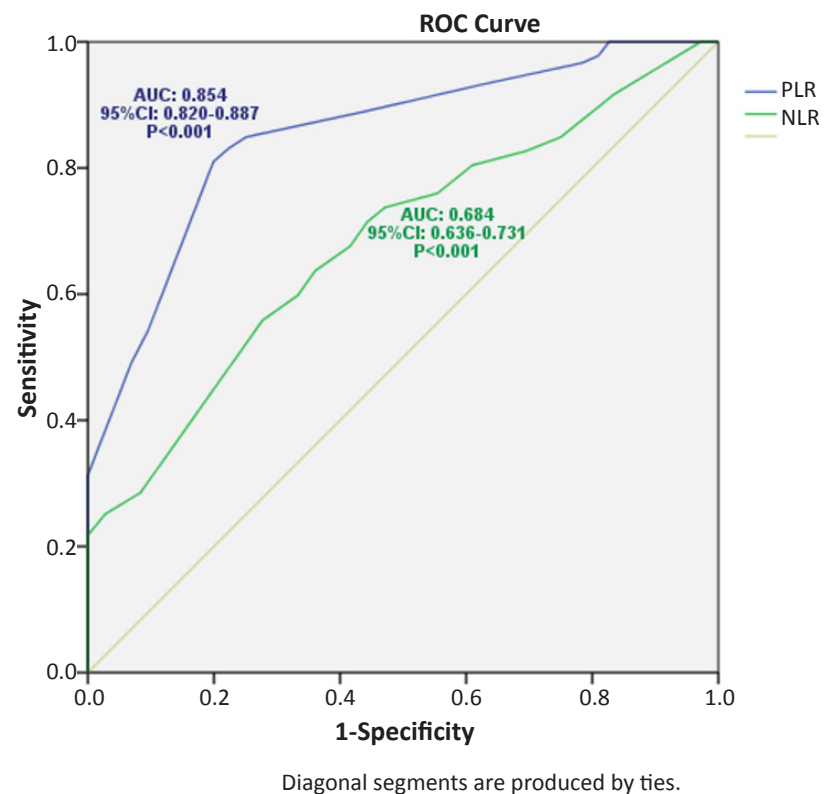

Figure 1. Details of the receiver operating characteristics (ROC) analysis of the effect of the PLR and NLR on postoperative SIRS after PNL.

\section{DISCUSSION}

PNL is a effective and safe minimally invasive technique used in the treatment of kidney stones. There are studies reporting complication rates between $3 \%$ and $83 \%{ }^{(2,11)}$. Serious infections that cause severe sepsis and septic shock are unusual, but if they do occur, they can be destructive (2). Sepsis is the most common cause of perioperative mortality ${ }^{(3,12)}$.

It is known that ischemia, inflammation, trauma, infection or their combination may cause SIRS, which is closely related with sepsis ${ }^{(5-8)}$. NLR has been suggested as an infectious marker in sepsis and it has been found to be associated with severity of disease ${ }^{(13)}$. Gürol et al. ${ }^{(14)}$ emphasized that the cut off value of 5 for NLR is quite successful in predicting sepsis and bacteremia. Many studies have reported that PLR and NLR are closely related with gastrointestinal and genitourinary system tumors ${ }^{(15-18)}$. Proctor et 
al.'s (19) large-scale study that evaluated 27,000 patients reported that PLR was effective in foreseeing the results of numerous types of cancers. However, there are limited studies investigating the occurrence of SIRS after PNL ${ }^{(8,20)}$, and both PLR and NLR rates were reported in very few of these studies ${ }^{(5,9)}$.

Operative time, stone burden, access number, and blood transfusion have been reported to be predictors of SIRS or postoperative fever (5,20-22). According to Chen et al., (20) the significant risk factors for development of SIRS after PNL are blood transfusion, number of tracts, pyelocaliectasis, and stone size, however NLR or PLR were not evaluated. They reported that presence of these risk factors was associated with more than 20 -fold increase in the SIRS development ${ }^{(20)}$. In a study examining the relationship between NLR and sepsis, the percentage of sepsis was significantly higher in the group with NLR $\geq 2.50$ compared to the group with NLR $<2.50$ (6). Çetinkaya et al. ${ }^{(5)}$ reported that preoperative PLR is an inexpensive and effective biomarker to foresee SIRS after PNL. They recommended that patients with a PLR> 114.1 should be closely monitored due to the possibility of serious complications. The same study showed that preoperative PLR and NLR were associated with the development of SIRS ${ }^{(5)}$. Another study stated that NLR is an independent predictive factor for postPNL SIRS, while PLR rate was also significantly higher in the group with SIRS ${ }^{(9)}$.

Similar to the literature, the results of our study showed that staghorn stone, increased blood transfusion, stone volume, NLR, and PLR were associated with postoperative SIRS (5,6,9,20-22). In addition, this is the first study that showed that high preoperative creatinine level and higher rate of increase in postoperative creatinine level were associated with the development of SIRS. Previous studies have shown that serum creatinine level was higher, albeit not significantly, in patients who developed SIRS after PNL ${ }^{(9)}$. We think that the higher creatinine level might have triggered systemic inflammation in some way. The results of our study did not reveal a relationship between operation time, number of accesses and SIRS.

Multivariate logistic regression analyzes showed that NLR, PLR, and blood transfusion were independently associated with SIRS. ROC curve analysis determined the NLR value of 120.5 (sensitivity $=81 \%$, specificity= $80.1 \%$ ) and PLR value of 2.75 (sensitivity $=63.7 \%$, specificity $=64 \%$ ) as cut-off points for predicting postoperative SIRS. Our rates of SIRS development after PNL (23.6\%) were similar to the studies in the literature that reported rates ranging between $16.7 \%$ and $27.4 \%$. Our results also showed that sepsis was seen at a significantly higher rate in the SIRS group (non-SIRS 1\%, SIRS group 4.5\%).

In addition to the factors analyzed in previous studies, here we report that PLR and NLR can predictor SIRS development after PNL. To the best of our knowledge, this is the third study on this subject and the study with the highest sample size. Its retrospective design is the primary limitation of our study. Therefore, inflammatory markers such as interleukin-6, C-reactive protein, tumor necrosis factor-alpha and sedimentation could not be evaluated. In addition, not performing intraoperative urinalyses and stone culture and lack of stone analyses are other limitations.

\section{CONCLUSION}

Prediction of SIRS, which may be associated with sepsis and other complications, is important for both the patient and the physician. Based on our findings, we recommend that patients with PLR $>120.5$, NLR $>2.75$, and those who underwent blood transfusion should be followed up closely and carefully in the postoperative period. These markers are basic, easily measurable, and effortless to use in diurnal praxis at no extra cost. However, more exhaustive prospective studies are required to backing the findings of our study. 
Ethics Committee Approval: S.B.U. Tepecik Training and Research Hospital Clinical Research Ethics Committee approval was obtained (Institutional review board approval number: 2021/03-01).

Conflict of Interest: All authors declare that there is no confict of interest.

Funding: None.

Informed Consent: Receipt.

\section{REFERENCES}

1. Türk C, Petř́́k A, Sarica K, Seitz C, Skolarikos A, Straub M, Knoll T. EAU Guidelines on Diagnosis and Conservative Management of Urolithiasis. Eur Urol. 2016;69(3):468-74. [CrossRef]

2. Michel MS, Trojan L, Rassweiler JJ. Complications in percutaneous nephrolithotomy. Eur Urol. 2007;51:899-906. discussion. [CrossRef]

3. O'Keeffe NK, Mortimer AJ, Sambrook PA, Rao PN. Severe sepsis following percutaneous or endoscopic procedures for urinary tract stones. Br J Urol. 1993;72:277-83. [CrossRef]

4. Rao PN, Dube DA, Weightman NC, Oppenheim BA, Morris J. Prediction of septicemia following endourological manipulation for stones in the upper urinary tract. J Urol. 1991;146:955-60. [CrossRef]

5. Cetinkaya M, Buldu I, Kurt O, Inan R. Platelet-to-Lymphocyte Ratio: A New Factor for Predicting Systemic Inflammatory Response Syndrome after Percutaneous Nephrolithotomy. Urol J. 2017;14(5):4089-93. PMID: 28853103.

6. Sen V, Bozkurt IH, Aydogdu O, Yonguc T, Yarimoglu S, Sen P, Koras O, Degirmenci T. Significance of preoperative neutrophil-lymphocyte count ratio on predicting postoperative sepsis after percutaneous nephrolithotomy. Kaohsiung J Med Sci. 2016;32(10):507-13. [CrossRef]

7. Gutierrez J, Smith A, Geavlete P, Shah H, Kural AR, de Sio M, Amón Sesmero JH, Hoznek A, de la Rosette J; CROES PCNL Study Group. Urinary tract infections and post-operative fever in percutaneous nephrolithotomy. World J Urol. 2013;31(5):1135-40. [CrossRef]

8. Erdil T, Bostanci Y, Ozden E, Atac F, Yakupoglu YK, Yilmaz AF, Sarikaya S. Risk factors for systemic inflammatory response syndrome following percutaneous nephrolithotomy. Urolithiasis. 2013;41(5):395-401. [CrossRef]

9. Tang K, Liu H, Jiang K, Ye T, Yan L, Liu P, Xia D, Chen Z, Xu H, Ye $Z$. Predictive value of preoperative inflammatory response biomarkers for metabolic syndrome and post-PCNL systemic inflammatory response syndrome in patients with nephrolithiasis. Oncotarget. 2017;8(49):85612-27. [CrossRef]

10. Chakraborty RK, Burns B. Systemic Inflammatory Response Syndrome. 2021 Mar 1. In: StatPearls [Internet]. Treasure
Island (FL): StatPearls Publishing; 2021. PMID: 31613449.

11. Skolarikos A, de la Rosette J. Prevention and treatment of complications following percutaneous nephrolithotomy. Curr Opin Urol. 2008;18:229-34. [CrossRef]

12. de la Rosette J, Assimos D, Desai M, Gutierrez J, Lingeman J, Scarpa R, Tefekli A; CROES PCNL Study Group. The Clinical Research Office of the Endourological Society Percutaneous Nephrolithotomy Global Study: indications, complications, and outcomes in 5803 patients. J Endourol. 2011;25(1):11-7. [CrossRef]

13. Zahorec R. Ratio of neutrophil to lymphocyte countsdrapid and simple parameter of systemic inflammation and stress in critically ill. Bratisl Lek Listy. 2001;102:5e14.

14. Gürol G, Çiftci İH, Terizi HA, Atasoy AR, Ozbek A, Köroğlu M. Are there standardized cutoff values for neutrophillymphocyte ratios in bacteremia or sepsis? J Microbiol Biotechnol. 2015;25(4):521-5. [CrossRef]

15. Hsu JT, Liao CK, Le PH, Chen TH, Lin CJ, Chen JS, Chiang KC, Yeh TS. Prognostic Value of the Preoperative Neutrophil to Lymphocyte Ratio in Resectable Gastric Cancer. Medicine (Baltimore). 2015;94(39):e1589. [CrossRef]

16. Carruthers R, Tho LM, Brown J, Kakumanu S, McCartney E, McDonald AC. Systemic inflammatory response is a predictor of outcome in patients undergoing preoperative chemoradiation for locally advanced rectal cancer. Colorectal Dis. 2012;14:e701-7. [CrossRef]

17. Sidaway P. Prostate cancer: Platelet-to-lymphocyte ratio predicts prostate cancer prognosis. Nat Rev Urol. 2015;12:238. [CrossRef]

18. Lucca I, de Martino M, Hofbauer SL, Zamani N, Shariat SF, Klatte T. Comparison of the prognostic value of pretreatment measurements of systemic inflammatory response in patients undergoing curative resection of clear cell renal cell carcinoma. World J Urol. 2015. [CrossRef]

19. Proctor MJ, Morrison DS, Talwar D, Balmer SM, Fletcher CD, O'Reilly DS, Foulis AK, Horgan PG, McMillan DC. A comparison of inflammation-based prognostic scores in patients with cancer. A Glasgow Inflammation Outcome Study. Eur J Cancer. 2011;47(17):2633-41. [CrossRef]

20. Chen L, Xu QQ, Li JX, Xiong LL, Wang XF, Huang XB. Systemic inflammatory response syndrome after percutaneous nephrolithotomy: an assessment of risk factors. Int J Urol. 2008;15:1025-8. [CrossRef]

21. Kreydin El, Eisner BH. Risk factors for sepsis after percutaneous renal stone surgery. Nat Rev Urol. 2013;10:598e605. [CrossRef]

22. Mariappan P, Smith G, Bariol SV, Moussa SA, Tolley DA. Stone and pelvic urine culture and sensitivity are better than bladder urine as predictors of urosepsis following percutaneous nephrolithotomy: a prospective clinical study. J Urol. 2005;173:1610e4. [CrossRef]

23. Koras $\mathrm{O}$, Bozkurt IH, Yonguc T, Degirmenci T, Arslan B, Gunlusoy B, Aydogdu O, Minareci S. Risk factors for postoperative infectious complications following percutaneous nephrolithotomy: a prospective clinical study. Urolithiasis. 2015;43(1):55-60. [CrossRef] 